Article

\title{
Biocidal Activity of Phyto-Derivative Products Used on Phototrophic Biofilms Growing on Stone Surfaces of the Domus Aurea in Rome (Italy)
}

\author{
Lorenza Rugnini $^{1}$, Giada Migliore ${ }^{2}$, Flavia Tasso ${ }^{2}$, Neil Thomas William Ellwood ${ }^{3}$ (D), \\ Anna Rosa Sprocati ${ }^{2}$ and Laura Bruno ${ }^{1, *(1)}$ \\ 1 LBA-Laboratory of Biology of Algae, Department of Biology, University of Rome "Tor Vergata", \\ via Cracovia 1, 00133 Rome, Italy; rgnlnz01@uniroma2.it \\ 2 ENEA, Territorial and Production Systems Sustainability Department, via Anguillarese 301, \\ 00123 Rome, Italy; giada.migliore@enea.it (G.M.); flavia.tasso@enea.it (F.T.); \\ annarosa.sprocati@enea.it (A.R.S.) \\ 3 Department of Science, University of Roma Tre, Viale G. Marconi 446, 00146 Rome, Italy; \\ ellwood@uniroma3.it \\ * Correspondence: laura.bruno@uniroma2.it
}

Received: 23 July 2020; Accepted: 16 September 2020; Published: 21 September 2020

\begin{abstract}
Hypogean or enclosed monuments are important cultural heritage sites that can suffer biodegradation. Many of the stone walls of the prestigious Domus Aurea are overwhelmed by dense biofilms and so need intervention. Room 93 was chosen as a study site with the aim to test the efficacy of phyto-derivatives as new biocides. Laboratory studies were performed comparing the effects of liquorice leaf extract (Glycyrrhiza glabra L.), lavender essential oil (Lavandula angustifolia Mill.) and a combination of both. In situ studies were also performed to test the effect of liquorice. The results were compared with those of the commonly used synthetic biocide benzalkonium chloride. The effects on the biofilms were assessed by microscopy along with chlorophyll fluorescence analysis. The phototrophs in the biofilms were identified morphologically, while the heterotrophs were identified with culture analysis and 16S gene sequencing. Results showed that the mixed solution liquorice/lavender was the most effective in inhibiting the photosynthetic activities of biofilms in the laboratory tests; while, in situ, the effect of liquorice was particularly encouraging as an efficient and low-invasive biocide. The results demonstrate a high potential biocidal efficacy of the phyto-derivatives, but also highlight the need to develop an efficient application regime.
\end{abstract}

Keywords: cultural heritage; biodeterioration; biofilms; cyanobacteria; biocides; phyto-derivative; liquorice; lavender; PAM

\section{Introduction}

Conservation of stone surfaces, in hypogea or in confined monuments, is threatened by the addition of artificial lighting that is essential for visibility; however, when it is combined with humidity, nutrient availability and particular physical substrate characteristics, light facilitates the colonisation by biodeteriorative biofilms [1-3]. These biofilms are formed by diverse microbial communities of cyanobacteria, bacteria and, to a lesser extent, by algae and fungi [4,5]. Different studies have demonstrated their deleterious effects (aesthetical, chemical and physical) on diverse substrates (stone and painted surfaces [6,7], as well as other valuable cultural heritage materials [8-10]). While there is the desire to rid surfaces from these deteriogenic biofilms, the general confinement of these sites hinders the use of chemical biocides, even if they are effective, as they cause major health issues for operators. These biocides also tend to be polluting substances that can persist in the natural 
environment [11]. While biocides regularly used in the restoration field (e.g., benzalkonium chloride, nystatin and sodium fluoride, among others) have known bacterial, fungal and insecticidal activities [12], their effectiveness on algae and cyanobacteria is still not fully understood.

The challenge is now to develop more safe and sustainable methods in the restoration and conservation of lithic cultural heritage using products and practices that take environmental, social and economic aspects into account [13-17]. This challenge will involve players from multiple disciplines, i.e., not only restorers and art historians, but also scientific researchers, politicians, entrepreneurs and economists. The most notably harmful products in use are being eliminated from the market and others should follow, and the search for new bio-based and sustainable products, as replacements, could open a new potential market in the bioeconomy chain. Substitution with safer alternatives and greener technologies is strongly driven by regulation and contributes to the overarching EU objectives for a non-toxic environment and a circular economy [18].

Among the alternative treatments to be investigated, plant extracts are showing promise as biocides by having many advantages over the traditional synthetic options. They are environmentally friendly (biodegradable) and have a functional complexity, which is thought to evade the possibility of resistance, one of the main negative characteristics of synthetic biocides. Plant-based biocides are generally alcohol extracts or essential oils that have been used in medical, food and pharmaceutical industries. Their effectiveness against common human pathogens including bacteria, fungi and yeasts is well-known, but more recently tests on their antimicrobial activity against organisms associated with biodeterioration of archives, libraries, museums and stone monuments have been carried out [12,13,19]. In the present study, liquorice leaf extract and lavender essential oil were chosen for two reasons: the biofilms to be treated are complex communities, and the ineffectiveness of the synthetic biocides previously used, which required ever more frequent treatments (data not published).

While the antimicrobial activity (against bacteria and fungi) of liquorice (Glycyrrhiza glabra L.) root extracts has been well established [20-22], less is known about the full biocidal potential of liquorice leaf extracts. Two antimicrobial flavonones were isolated from the leaves of G. glabra: Pinocembrina and lycoflavanone [23]. A comparative study on the antimicrobial effects of leaf and root ethanolic extracts carried out on human pathogenic microorganisms demonstrated that there was overlapping activity and that the leaf extract was more effective against some strains $[24,25]$. Leaf extract has also been used as a fungicide for agricultural purposes [26]. The biocidal effect of the leaf extract was shown to be effective against 20 bacterial strains and 10 fungal strains isolated from hypogean environments (held in the ENEA collection), frescoes, wall and canvas paintings [27]. Furthermore, the use of an agri-food waste, such as liquorice leaves, fully meets the circular economy criterium. The use of a mixture of essential oils, Lavandula angustifolia Mill. (10\%) and Thymus vulgaris L. (1\%) (1:1 v:v mixture) has also been used on hypogean biofilms with positive biocidal effect on photosynthetic biofilms [13].

The aim of the present study is to determine the biocidal activity of liquorice leaf extract and lavender essential oils on biofilms growing on enclosed illuminated stone surfaces. The site chosen for the study is the Domus Aurea, which is a highly valuable Roman cultural heritage site, originally commissioned by Emperor Nero as a new residence after the devastating fire of $64 \mathrm{AD}$. The palace, famous for its sumptuous decoration, consisted of a series of buildings separated by gardens, woods, vineyards and an artificial lake (Figure 1). After Nero's death, successive emperors decided to erase all traces of Nero and his palace and the luxurious chambers were deprived of any valuables and filled up with soil to be used as foundations for other buildings and they remained undiscovered until the Renaissance (15th and 16th centuries). Unbeknownst to Nero's successors, the infilling of the Domus Aurea's rooms resulted in their conservation throughout the centuries. 

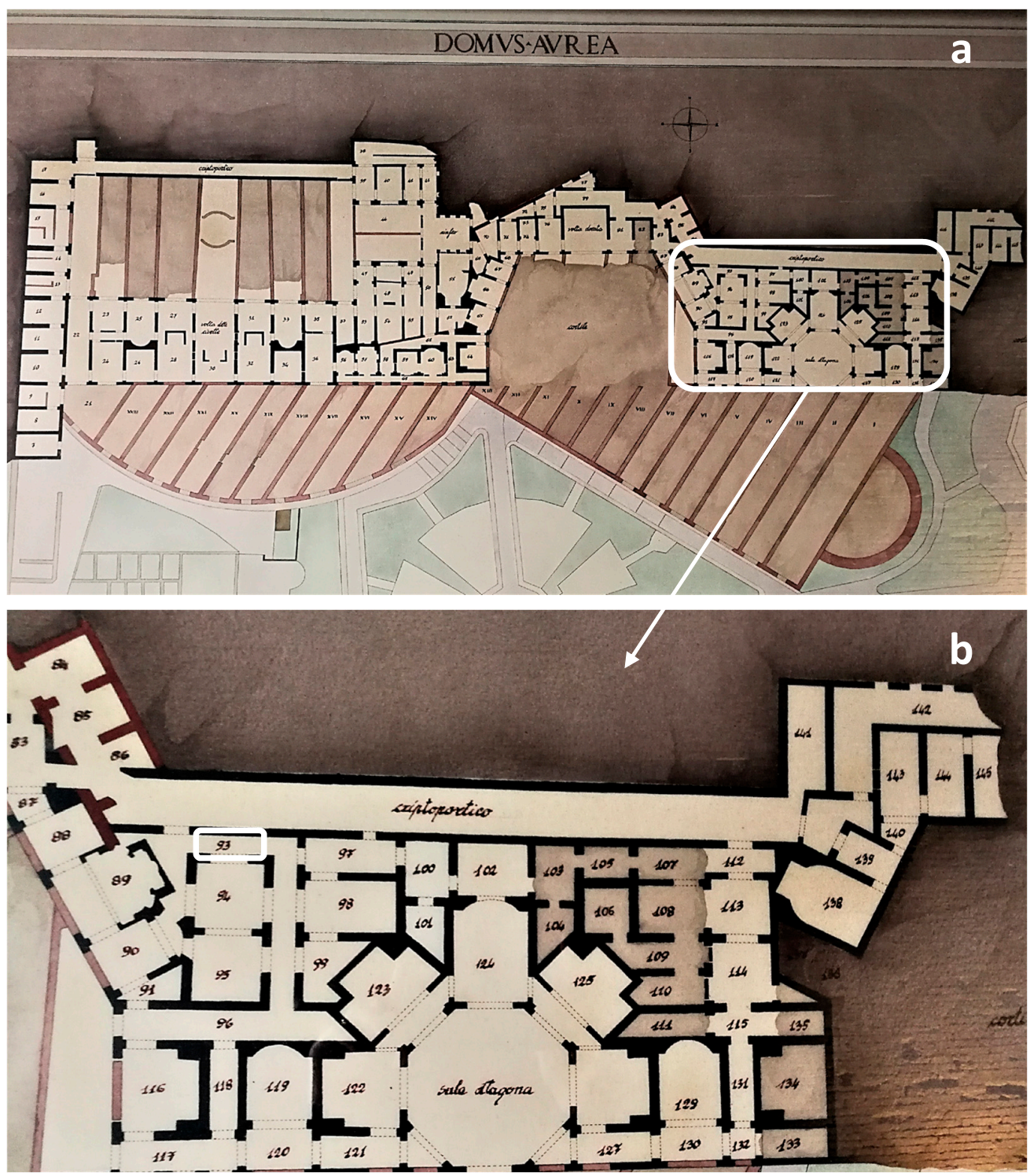

Figure 1. (a) Map of the remains of the Domus Aurea which consists of a series of buildings separated by gardens, woods and vineyards; (b) a detail of the area where the study site, Room 93, is located.

The Domus Aurea was opened to the public in 1999, but six years later was closed due to detachments and security problems, to open again in 2007 with restricted visits. However, due to artificial lighting, high humidity levels and residual soil heaps, many illuminated surfaces have been heavily infested by both phototrophic and heterotrophic biofilms. In the present study, phyto-derivatives were initially tested for their biocidal activity in a set of well plate experiments on the biofilms collected from surfaces in the Domus Aurea. Tests were then carried out on the natural biofilms occurring on a selected wall of Room 93 to show the efficacy of the treatment in situ. It was expected that the biocidal activity of the phytoextracts would be significant, and the tests should help develop safe, yet effective, protocols for the control of biofilm growth in enclosed, lithic environments.

\section{Materials and Methods}

\subsection{Sampling Site}

The biofilms used for the tests reported in this article were collected at the Domus Aurea in the Palatine Hill, Rome, Italy (Figure 1). A wall in Room 93 was selected for the sampling due to the evident biodeterioration of the surface (white, green and blue-green patinas). The wall in 
opus latericium is covered with soil which was not completely removed during the excavations. The biofilm was consistently and evenly distributed (Figure 2). Room 93 is adjacent to the Criptoportico and, although not part of the tourist route, it is illuminated by fluorescent lamps. In 2012, the wall was treated with Preventol ${ }^{\circledR}$ RI80, which is a solution of quaternary ammonium salts with a broad spectrum of activity (fungi, bacteria and algae). Previous intervention by the restorers consisted in spraying the biocidal product (diluted to 3\% with de-ionised water) on the surface and this was effective only after multiple applications with prolonged laying time. However, the recolonization was very fast (data not published).

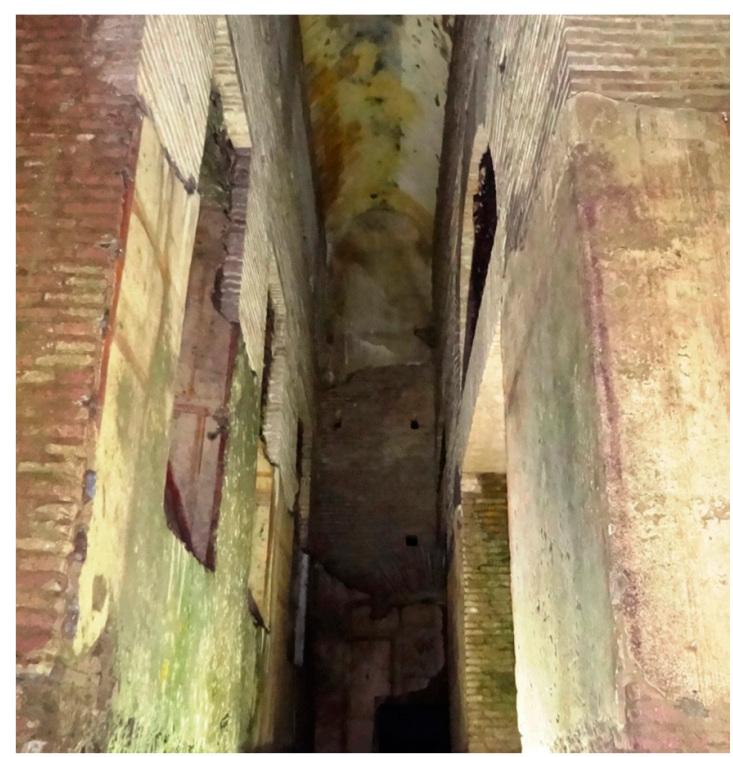

(a)

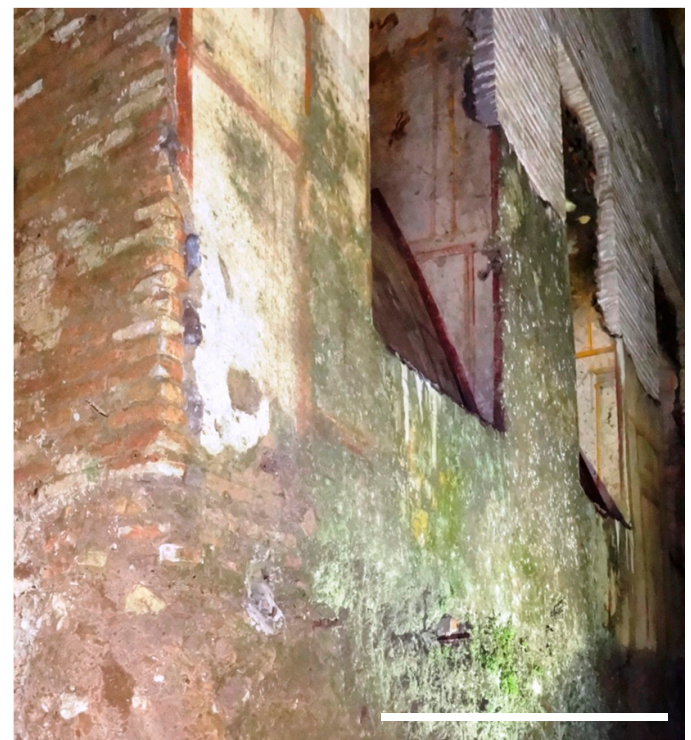

(b)

Figure 2. Two different views of the sampling site in Room 93 with the evident phototrophic biofilms causing discolouration of the walls. (a) front view of the corridor present in Room 93; (b) detailed image of the wall object of the investigation with the evident presence of the green biofilm; scale bar = $2 \mathrm{~m}$.

Environmental parameters in Room 93 were measured on each sampling trip and during each visit during the in-situ experimental period (about 75 days). Temperature $\left(\mathrm{T}^{\circ} \mathrm{C}\right)$ and relative humidity (RH\%) were measured using a digital humidity and temperature meter (CEM, model DT-625). Surface temperatures were made using a DT-8833 infrared thermometer (Thermosense, UK) and cross-checked using a Type $\mathrm{K}$ thermocouple resistor (Thermosense, model HK-400). Irradiance was measured using a radiometer (model LI-185B; LI-COR Inc., Lincoln, NE, USA) equipped with a quantum sensor (LI-190SB) to give PPFD in $\mu \mathrm{mol}$ photons $\mathrm{m}^{-2} \mathrm{~s}^{-1}$.

\subsection{Sampling of Biofilms and Microscopy Observations}

Ten samples of biofilm were collected using the method of adhesive tape strips (MAT; Fungitape Did, Milan, Italy) as a non-destructive sampling method [28]. Fresh samples were mounted on glass sides and were observed with a Zeiss AxioScope light microscope with a 40x objective; images were acquired with a digital camera (Canon EOS 600D-Canon S.P.A., Milan, Italy). The adhesive tape samples were also observed using a Confocal Laser Scanning Microscope (CLSM) FV1000 (Olympus Corp., Tokyo, Japan), with a $60 \times$ objective using the autofluorescence channels for chlorophyll $a$ and phycobiliproteins (excitation 488, 543, $635 \mathrm{~nm}$, emission 520, 572 and $688 \mathrm{~nm}$ ). Three-dimensional images were constructed from a series of 2D cross-sectional images ( $x-y$ plane) that were captured at 0.5- $\mu \mathrm{m}$ intervals along the z-axis using IMARIS 6.2.0 software (Bitplane AG Zurich, Switzerland). The identification of the cyanobacteria present in the samples was made according to the recent taxonomy of cyanobacteria [29,30]. 


\subsection{Heterotrophic Microorganisms}

The biofilm was fully characterised by culture-dependent and independent techniques. The cultivable portion of the heterotrophic community was first studied, to isolate the microorganisms and use them for subsequent in vitro investigation for individual sensitivity to the tested biocides. To characterise the cultivable portion of the heterotrophic community inhabiting the biofilm, $20 \mathrm{~g}$ of biomass was sampled from random points in a selected area of $2 \times 2 \mathrm{~m}$ by gently scraping off the biofilm with sterile scalpels; $5 \mathrm{~g}$ of the mixed sampled biofilms were then suspended in a $50 \mathrm{~mL}$ solution of sodium pyrophosphate and Tween $80(0.05 \%$ and $0.001 \% v / v$ respectively). The suspension was then kept in an orbital shaking incubator (New Brunswick ${ }^{\mathrm{TM}}$ Innova 4430-New Brunswick Scientific Co Inc, Edison, NJ, USA) at $28^{\circ} \mathrm{C}$ and $150 \mathrm{rpm}$ for $1 \mathrm{~h}$. The number of cultivable heterotrophic microorganisms was obtained by plating $100 \mu \mathrm{L}$ of suspension and following serial dilutions in three different agar media: Tryptic Soy Agar (TSA, Conda, Spain) and Mineral Medium (MM, Schmidt and Schlegel, 1989) added with $0.5 \%(w / v)$ sodium gluconate and $1.5 \%$ agar (Agar, Conda, Spain) for bacteria and Potato Dextrose Agar (PDA, Conda, Spain) for fungi. The plates were then incubated at room temperature until the complete growth of colonies (up to one month).

The isolation of bacterial and fungal strains was based on colony morphologies. Colonies were streaked three times on the same agarized medium from which they were isolated, in order to obtain pure cultures. The plates were then incubated at room temperature until there was complete colony development (24-72 h). Bacterial strains were identified by $16 \mathrm{~S}$ r-DNA sequencing. Genomic DNA was extracted by resuspending two fresh colonies of each isolate in $20 \mu \mathrm{L}$ of lysis buffer $(\mathrm{NaOH} 0.5 \mathrm{M}$ and SDS $0.5 \% w / v)$, heating at $95^{\circ} \mathrm{C}$ for $15 \mathrm{~min}$ and then transferring to an ice bath for $15 \mathrm{~min}$. The $16 \mathrm{~S}$ r-DNA complete gene was PCR amplified by using $9 \mathrm{bfm}$ as a forward and $1512 \mathrm{uR}$ as a reverse primer [31]. The reaction mixture contained $1 \times$ PCR Master Mix (Thermo Scientific, Waltham, MA, USA), $2 \mu \mathrm{L}$ of template DNA and $20 \mathrm{pmol}$ of each primer in the total reaction volume of $25 \mu \mathrm{L}$. The PCR products were sequenced by a commercial facility. Sequence identities were analysed using the National Center for Biotechnology Information (NCBI) BLAST program (https://blast.ncbi.nlm.nih.gov/Blast.cgi) and the GenBank database. Each isolate was compared against known taxa present in the database. A preliminary identification of the fungal isolates was done according to typical colonial and conidial morphology using a stereo microscope.

\subsection{Laboratory Treatments with Phyto-Derivatives}

Two phyto-derivatives were tested for their biocide activity: liquorice alcoholic leaf extract (Glycyrrhiza glabra L.) (LIQ) and lavender essential oil (Lavandula angustifolia Mill.) (LAV). The liquorice alcoholic leaf extract at 50\% (w/v) was provided by Trifolio-M GmbH (Lahnau, Germany), while the lavender essential oil was supplied by Sarandrea Marco \& CO. S.r.l. (Collepardo, Italy).

In the first set of experiments the collected biofilms $(5 \mathrm{~g})$ were homogenised prior to inoculation on to agarized BG11 growth medium. Once extensive growth of the biofilm was observed, they were treated with LAV $(5 \% v / v)$, LIQ $(10$ and $30 \% v / v)$ and sterile saline solution $(\mathrm{NaCl} 0.9 \% w / v)$ as control (CTRL). Each treatment was tested in triplicate. The extracts were prepared by diluting with distilled water to the desired concentration. In the preparation of the LAV 5\%, the solution was emulsified using $1 \%$ TWEEN 20. Two applications of $100 \mu \mathrm{L}$ of each treatment were performed at time 0 and 5 days.

Photosynthesis, the most fundamental and intricate physiological process in phototrophic organisms, is highly sensitive to the majority of stresses (biotic or abiotic) [32]. Therefore, a measure of chlorophyll fluorescence could be considered as a good indicator of the effect of plant extracts on the vitality of the biofilm phototrophic component. A mini-PAM portable fluorometer was used to measure the maximum quantum yield immediately before each treatment (days 1 and 5) and then at 5 , 30 and $90 \mathrm{~min}, 1$ and 5 days after each treatment (10 days in total).

The second test involved the remaining $15 \mathrm{~g}$ of biofilm sampled from the selected area on the wall, which was then homogenized and transferred into 24 well plates. In each well, $250 \mathrm{mg}$ of biofilm was placed on a sterile nitrocellulose filter and treated with either LIQ (10\%), LAV (5\%) or a mixture of 
LIQ10\% and LAV5\% (LIQLAV). As a positive control the chemical biocide benzalkonium chloride 50\% (Antichità Belsito, Rome, Italy) was applied at $0.6 \%$ (v/v) (BENZ). As negative control, the biofilm was treated with sterile saline solution (CTRL). All the tests were done in triplicate. Measures of maximum quantum yield were conducted immediately before the application of each treatment $(100 \mu \mathrm{L})$ and then after 5 days. In order to avoid the cross contamination of treatments, one well plate was used for each substance.

To evaluate the biocide effect on the heterotrophic microorganisms, the nitrocellulose filters supporting the biofilm were weighed and suspended $1: 10 \mathrm{w} / \mathrm{v}$ in a solution of sodium pyrophosphate $(0.05 \%)$ and Tween $80(0.001 \%)$. The suspensions were incubated in an orbital shaker at $28{ }^{\circ} \mathrm{C}$ and $150 \mathrm{rpm}$ for $1 \mathrm{~h}$. The number of cultivable heterotrophic microorganisms was obtained by plating $100 \mu \mathrm{L}$ of suspension and following decimal dilutions in TSA, MM and PDA agar media. The plates were then incubated at room temperature until the complete growth of colonies. Counts of viable microorganisms were referred to as colony forming units per gram of wet biofilm (CFU/g wet biofilm).

\subsection{In Situ Application of Phyto-Derivatives}

Following the well plate experiments, the phyto-derivatives were tested in situ. Unfortunately, according to the safety limitation for the application of substances in the Domus Aurea's archaeological restoration site, it was not possible to test in situ the lavender essential oil.

Three areas of Room $93(15 \times 6 \mathrm{~cm}$, each one) were selected that had a homogenous biofilm covering. Each area was treated by spraying separate treatments directly onto the surface using a stencil protector to restrict the application to the treatment area only; LIQ $(10 \%)$, BENZ $(0.6 \% \mathrm{v} / \mathrm{v})$ and CTRL (sterile saline solution) were employed. Two applications were performed, at time 0 and after 14 days. Effective quantum yield was measured immediately before each treatment application and then 5 min afterwards; follow-up measurements were made on days 7, 14, 35 and 76. Coinciding with the yield measurements, in situ micrographs $(200 \times$ max) were taken before and after treatments on biofilms using a Handheld Digital Microscope (USB) Dino-Lite Premier 1.3MP (AnMo Electronics Corporation, New Taipei City, Taiwan). Observations of biofilm samples collected using adhesive tape strips were also conducted at the light microscope $(40 \times)$ and at the stereo microscope $(1.6 \times)$ Zeiss, Stemi 508 (Carl Zeiss Microscopy GmbH, Jena, Germany) equipped with a digital camera Axiocam ERc 55 (Carl Zeiss Microscopy GmbH, Jena, Germany).

\subsection{Photosynthetic Parameters}

To evaluate the biocidal effects of the applied phyto-derivative products, photosynthetic parameters (chlorophyll fluorescence) of the biofilms were measured using the pulse amplitude modulated fluorometer Mini-PAM of Heinz Walz (Effeltrich, Germany) both on-site and in the laboratory. In situ measurements were made using a holder that maintained the fibre-optic probe at $60^{\circ}$ to the surface (to not block the natural light levels), and $6 \mathrm{~mm}$ from the biofilm to allow comparisons to be made among sites (in the laboratory, the probe was held perpendicular to the samples). In the laboratory, the maximum potential quantum yields $\left(\mathrm{F}_{\mathrm{v}} / \mathrm{F}_{\mathrm{m}}\right)$ were assured by performing the measurements made in quasi-darkness $\left(<1 \mu \mathrm{mol}\right.$ photons $\left.\mathrm{m}^{-2} \mathrm{~s}^{-1}\right)$, whilst the effective quantum yield $\left(\mathrm{F}_{\mathrm{v}^{\prime}} / \mathrm{F}_{\mathrm{m}^{\prime}}\right)$ was measured in situ [33]. Correlations, T-tests, ANOVA and post hoc tests were carried out using SPSS (v. 23 IBM).

\section{Results and Discussions}

\subsection{Macro and Micro-Environmental Conditions}

As expected, the environmental conditions were relatively stable in Room 93 with temperatures of $17.0 \pm 0.5{ }^{\circ} \mathrm{C}$, humidity $88 \pm 2 \%$ and light irradiance of $1.0 \pm 0.2 \mu \mathrm{mol}$ photons $\mathrm{m}^{-2} \mathrm{~s}^{-1}$. Surface temperature, where the MAT method was employed for biofilm collection, was around $8.0^{\circ} \mathrm{C}$. These environmental conditions are typical of hypogean and confined environments $[3,5]$ and remained stable due to the lower number of visitors in this area of the site. 


\subsection{Biofilm Characterization}

Observations using light and confocal microscopy (Figure 3) showed that the biofilm was mainly composed of filamentous cyanobacteria typical of low light environments [4,34]. In particular, the cyanobacterium Scytonema julianum was shown to be the dominant species in the biofilm growing in Room 93 of the Domus Aurea, along with Leptolyngbya sp. and Symphyonemopsis sp. As previously observed [13], growth of these heterocytous-nitrogen fixing species is normally favoured in these nutrient poor environments. The dominance by S. julianum was particularly worrisome as it is considered highly biodeteriogenic in that it causes extensive calcium carbonate precipitates by dissolution of minerals from the substrata $[11,13]$.

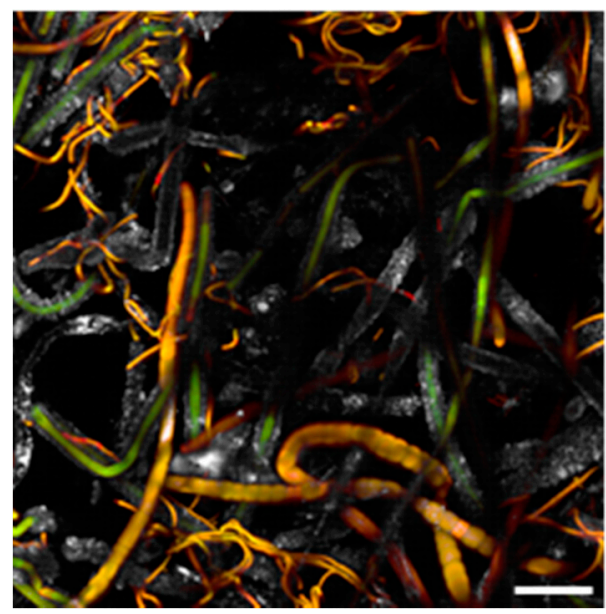

Figure 3. Biofilm sample taken from the wall of Room 93 and observed at the Confocal Laser Scanning Microscope (CLSM); the biofilm is dominated by S. julianum (thick filaments) and Leptolyngbya sp. (thin filaments). Scale bar $=40 \mu \mathrm{m}$.

\subsection{Associated Heterotrophic Microorganisms}

The microbial load composed of heterotrophic bacteria in the collected biofilm was $5.55 \pm 0.6$ $\left(\times 10^{7} \mathrm{CFU} / \mathrm{g}\right.$ of wet biofilm), $5.4 \pm 0.8\left(10^{7} \mathrm{CFU} / \mathrm{g}\right.$ of wet biofilm) and $3.6 \pm 0.3\left(10^{5} \mathrm{CFU} / \mathrm{g}\right.$ of wet biofilm) on TSA, MM and PDA mediums, respectively. Based on colony morphologies, ten bacterial strains were isolated and identified (Table 1), belonging to three main phyla: Proteobacteria (class Alpha and Gamma), Actinobacteria and Bacteroidetes.

Table 1. Phylogenetic affiliation by $16 \mathrm{~S}$ r-DNA sequencing of the bacterial strains co-occurring in the sampled biofilm. The strains have been named with the abbreviation DA followed by a progressive number.

\begin{tabular}{cccc}
\hline Strain Name & Phylum & Species & ID \% \\
\hline DA1 & Bacteroidetes & Chriseobacterium plytrichastri & 98 \\
DA2 & Proteobacteria & Ensifer adhaerens & 98 \\
DA3 & Proteobacteria & Inquilinus ginsengisoli & 96 \\
DA4 & Proteobacteria & Pseudomonas asplenii & 97 \\
DA5 & Proteobacteria & Pseudomonas glareae & 97 \\
DA6 & Proteobacteria & Pseudomonas helmanticensis & 99 \\
DA7 & Proteobacteria & Pseudomonas vancouverensis & 99 \\
DA8 & Actinobacteria & Rhodococcus jostii & 98 \\
DA9 & Actinobacteria & Rhodocossus koreensis & 98 \\
DA10 & Actinobacteria & Streptomyces spororaveus & 99 \\
\hline
\end{tabular}

Only a few colonies of fungal strains were grown on PDA plates, but not yet identified. 
The presence of both heterotrophic and phototrophic microorganisms within the biofilm suggests that they may be acting in synergy and could actually be causing the enhancement of hypogean biodeterioration processes. Bacteria and fungi can proliferate using the organic matter released by phototrophs and in turn secreting acidic organic compounds that can solubilize the minerals of the substratum, which are in turn utilised by the algal component [35]. The strain Ensifer adhaerens DA2 participate as a nitrogen-fixing agent.

In Roman Catacombs Actinobacteria (especially Streptomyces) and filamentous fungi (e.g., Sporotrichum, Aspergillus, Cladosporium, Penicillium, etc.) are commonly detected together with photosynthetic microbes [36]. They are widely distributed on stone monuments because of their filamentous growth and their ability to use a large range of nitrogen and carbon sources [37]. Moreover, in this study we have isolated some slime-forming bacteria, belonging to the genus Pseudomonas, already described in surface samples of the Roman Catacombs of St. Callixtus and Domitilla [37,38]. Slime-forming bacteria play an essential role in biofilm establishment, producing extracellular complex carbohydrates which ensure adhesion of microbial cells to surfaces, provide protection from environmental antimicrobials, serve as reservoirs for nutrients and create distinct architectures to facilitate further microbial adherence [39,40]. Members of Alpha Proteobacteria and Bacteroidetes were frequently found as heterotrophic components of biofilms affecting stone monuments [41,42].

\subsection{Effects of Phyto-Derivatives Treatments}

Preliminary tests on biofilms grown on agarised BG11 medium were carried out to compare the effects of lavender and liquorice extracts on the vitality of phototrophs. As shown in Figure 4, among the yield values of the controls there were no significant differences $(p>0.05)$; however, those of all the treated biofilms were significantly lower than the controls $(p<0.001)$.
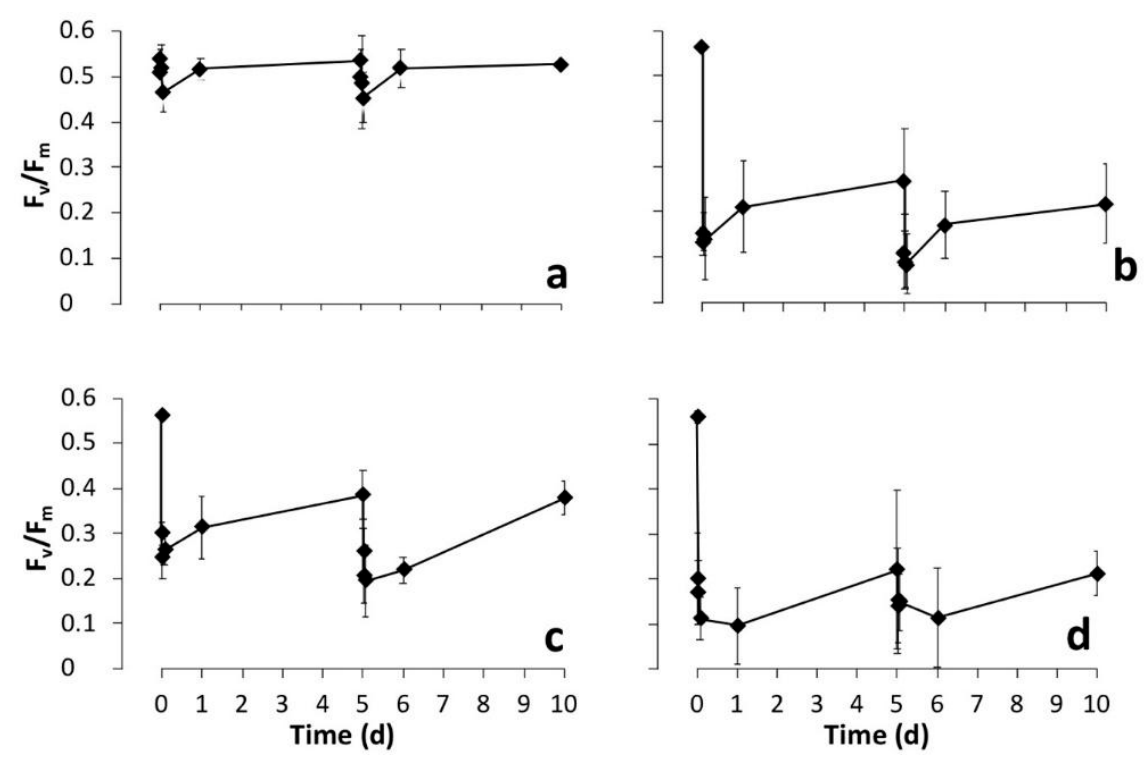

Figure 4. Changes over time of photosynthetic yield $\left(\mathrm{F}_{\mathrm{v}} / \mathrm{F}_{\mathrm{m}}\right)$ of cultured biofilms treated at days 0 and 5 with diverse phyto-derivatives, (a) control (CTRL), (b) lavender essential oil (Lavandula angustifolia Mill.) (LAV), (c) liquorice alcoholic leaf extract (Glycyrrhiza glabra L.) (LIQ) at 10\% and (d) 30\%. After each treatment measurements were made immediately, then at 5, 30 and $90 \mathrm{~min}, 1$ and 5 days (10 days in total).

The immediate reduction in yield of the controls and, to some extent, in the treatments, may be due to the partial submergence of the biofilm by addition of the treatment solution, which may have reduced gas exchange to the cell [43]. However, even after removal of this effect from the treatment yields (i.e., $\mathrm{F}_{\mathrm{v}} / \mathrm{F}_{\mathrm{m}}$ treated biofilm $-\mathrm{F}_{\mathrm{v}} / \mathrm{F}_{\mathrm{m}}$ control), there was still a $50 \%$ (LAV), 30\% (LIQ10) and $60 \%$ 
(LIQ30) reduction in $\mathrm{F}_{\mathrm{v}} / \mathrm{F}_{\mathrm{m}}$. There was a significant reduction in yields of the lavender and both the liquorice treated biofilms after five minutes $(p<0.001)$ and it remained so for the full 10 days. Therefore, it seems yield is susceptible to the two plant extracts, although the mode of action is not easy to determine. The minimal fluorescence $\left(\mathrm{F}_{\mathrm{o}}\right)$ values either remained relatively unchanged (LAV) or decreased (LIQ), actually indicating no photodamage [44], while a larger decrease in $\mathrm{F}_{\mathrm{m}}$ was observed that could represent enhanced nonradiative energy loss (heat dissipation) that may act in photo-protection or -repair [45]. In all treatments, yield did recover to some extent, rapidly within the first day, then slower until day five: Recovery from the maximum reduction was $20 \%$ for both treatments of LAV, $10 \%$ and $6 \%$ for LIQ10, $22 \%$ and $25 \%$ for LIQ30. This recovery is not thought to be a result of new growth; as observations of the biofilms did not indicate this, more likely, it was the occurrence of cellular repair of the photosynthetic apparatus. Yield responded similarly to the second treatment (day 5) —an initial decrease, followed by a slow partial recovery. This time the recovery resulted in yield values that were not significantly different to the initial (day 5) value $(p>0.05)$. However, yields did remain significantly lower than the original levels (day 0 ) during the experiment $(p<0.01)$. In a study of the recovery of structure and function of freshwater biofilms after being treated with short pulses of herbicide (Diuron) or bactericide (Triclosan), it was established that short biocide pulses can efficiently cause transient effects on biofilms, while longer pulses would result in more persistent effects with chronic ones that could be lethal to the biofilm [46]. In the scenario here using phytoextracts, given their volatile nature, they may behave in a similar manner to the through-flow pulse method and more frequent applications would be needed to determine if there is a chronic effect on biofilm status. A second test has been carried out inside well plates containing a piece of biofilm (250 mg each) evaluating the effect of two applications of LAV, LIQ and a mixed solution of both (LIQLAV) on photosynthetic and heterotrophic microorganisms. As shown in Figure 5 there were no significant differences between the yields before treatments and those of the control biofilms $(p>0.05)$.

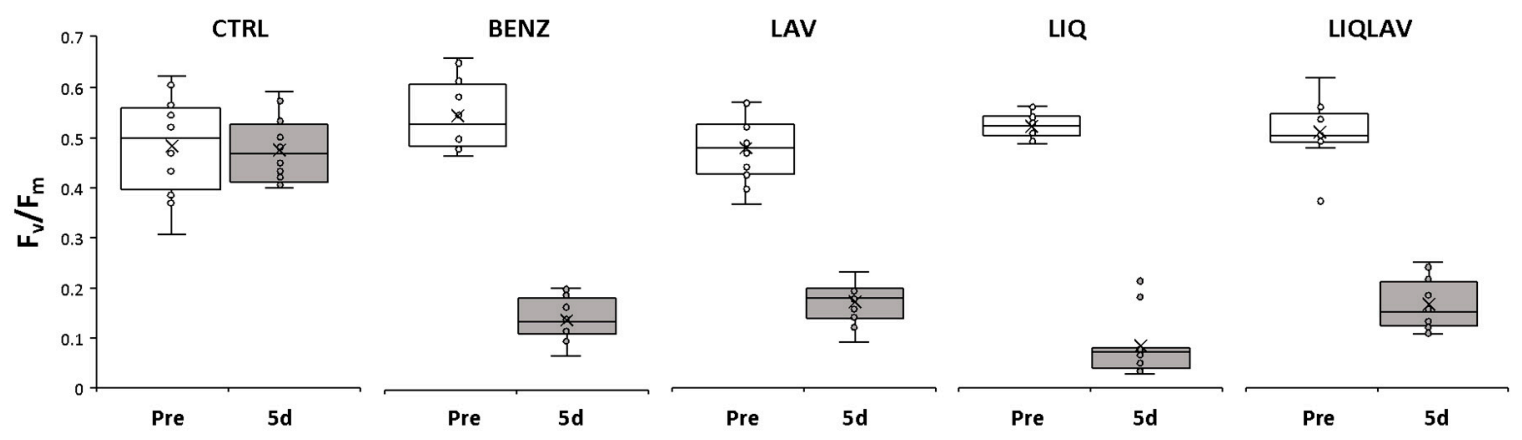

Figure 5. Changes in photosynthetic yield before each treatment (Pre) and after 5 days $(5 d)(n=12)$. Control (CTRL), benzalkonium (BENZ, positive control), lavender at $5 \%$ (LAV), liquorice at 10\% (LIQ) and a mixture of lavender $5 \%$ and liquorice $10 \%$ (LIQLAV).

The effects of the phyto-derivatives on the photosynthetic yield were comparable to the synthetic BENZ $(p>0.05)$ and resulted in significant lowering of yield $(p<0.01-0.001)$. One interesting aspect is the similar $\mathrm{F}_{\mathrm{v}} / \mathrm{F}_{\mathrm{m}}$ values for all treatments; the level indicating the presence of no viable photosynthesis was not determined. However, $\mathrm{F}_{\mathrm{v}} / \mathrm{F}_{\mathrm{m}}$ values lower than 0.1 have been proposed for other biofilms to indicate a total loss of photosynthetic activity $[47,48]$, which is similar to the values found in this study and may explain a great deal of the similarity in the response of the biofilms to the treatments. Concerning the effect of the treatments on the heterotrophic bacteria, in Table 2 are reported the microbial load and the number of bacterial strains found in the biofilms after the first and second application of the different phyto-derivatives in the well plates. 
Table 2. Colony forming units (CFUs) of cultivable heterotrophic bacteria in the different treatments after first and second application. CFU as referred to gram of wet biofilm. In the last column are reported the number of bacterial strains isolated after the second application.

\begin{tabular}{cccc}
\hline Treatments & I (CFU/g Wet Biofilm) & II (CFU/g Wet Biofilm) & $\begin{array}{c}\text { No. Bacterial Strains } \\
\text { after II Application }\end{array}$ \\
\hline CTRL & $(2.50 \pm 0.3) \times 10^{8}$ & $(1.00 \pm 0.5) \times 10^{8}$ & 6 \\
LIQ & $(1.20 \pm 0.2) \times 10^{9}$ & $(8.50 \pm 0.3) \times 10^{8}$ & 1 \\
LAV & $(6.20 \pm 0.5) \times 10^{9}$ & $(4.40 \pm 0.2) \times 10^{8}$ & 5 \\
LIQLAV & $(1.10 \pm 0.2) \times 10^{9}$ & $(3.50 \pm 0.4) \times 10^{8}$ & 3 \\
BENZ & $(2.60 \pm 0.3) \times 10^{8}$ & $(2.00 \pm 0.5) \times 10^{8}$ & 6 \\
\hline
\end{tabular}

Based on colony morphologies bacterial strains were isolated and identified. In Table 3 the bacterial strains isolated from the sampled biofilms and from the different treatments after the second application are reported. The DNA sequences have been submitted and we are awaiting the GenBank accession number.

Table 3. Phylogenetic identification by $16 \mathrm{~S}$ r-DNA sequencing of the bacterial strains from the sampled biofilm (in situ) and from the different treatments after the second application. The $\mathrm{X}$ indicates the occurrence of each strain in the different treatments.

\begin{tabular}{|c|c|c|c|c|c|c|c|c|}
\hline Strain nr & ID & $\begin{array}{c}\text { Sampled } \\
\text { Biofilm }\end{array}$ & CTRL & LIQ & LIQLAV & LAV & BENZ & Phylum \\
\hline DA17 & Brevundimonas alba & & & & & & $x$ & Proteobacteria \\
\hline DA1 & Chriseobacterium plytrichastri & $\mathrm{x}$ & & & & & & Bacteroidetes \\
\hline DA18 & Dyadobacter sp. & & & & & & $x$ & Proteobacteria \\
\hline DA2 & Ensifer adhaerens & $\mathrm{X}$ & $\mathrm{x}$ & & $\mathrm{x}$ & $\mathrm{x}$ & & Proteobacteria \\
\hline DA15 & Exiguobacterium mexicanum & & & & & $x$ & & Firmicutes \\
\hline DA3 & Inquilinus gingengisoli & $\mathrm{x}$ & & & & & & Proteobacteria \\
\hline DA19 & Lysovacter $s p$. & & & & & & $x$ & Proteobacteria \\
\hline DA11 & Mesorhizobium olivaresii & & $x$ & & & & & Proteobacteria \\
\hline DA16 & Microbacterium hydrocarbonoxydans & & & & & $x$ & & Actinobacteria \\
\hline DA20 & Phyllobacterium catacumbae & & & & & & $\mathrm{x}$ & Proteobacteria \\
\hline DA4 & Pseudomonas asplenii & $x$ & & $x$ & & & & Proteobacteria \\
\hline DA5 & Pseudomonas glaerae & $\mathrm{x}$ & $x$ & & $x$ & $x$ & $x$ & Proteobacteria \\
\hline DA6 & Pseudomonas helmanticensis & $\mathrm{X}$ & & & & & $\mathrm{X}$ & Proteobacteria \\
\hline DA7 & Pseudomonas vancouverensis & $\mathrm{x}$ & $\mathrm{X}$ & & & & & Proteobacteria \\
\hline DA12 & Pseudoxanthomonas dokdonensis & & $\mathrm{X}$ & & & & & Proteobacteria \\
\hline DA8 & Rhodococcus jostii & $\mathrm{x}$ & & & & & & Actinobacteria \\
\hline DA9 & Rhodococcus korensis & $x$ & & & & & & Actinobacteria \\
\hline DA13 & Sphingomonas desiccabilis & & $\mathrm{X}$ & & & & & Proteobacteria \\
\hline DA14 & Stenotrophomonas rhizophila & & & & $\mathrm{x}$ & $\mathrm{X}$ & & Proteobacteria \\
\hline DA10 & Streptomyces spororaveus & $\mathrm{x}$ & & & & & & Actinobacteria \\
\hline
\end{tabular}

Phyto-derivative treatments, as well as benzalkonium chloride, seemed to have little to no effect on the vitality of the heterotrophic bacteria in terms of total microbial load (Table 2), but did have an effect on the composition (Table 3). The diversity of the heterotrophic culturable community of the biofilms was lower in all the treatments, including the control, if compared to the sampled biofilm. However, this may be explained somewhat by the stress induced by the change of culture conditions when moving the biofilm from the original surface to the well plates; in particular, Actinobacteria and Bacteroidetes strains seemed particularly susceptible while the Proteobacteria predominated. This was especially true in the benzalkonium-treated biofilm. Proteobacteria strains, in particular Pseudomonas spp., are metabolically active Gram-negative able to use a wide variety of macromolecules, including the organic cell debris originating by the death of biocide-sensitive components of the microflora [11]. In spite of this, the treatment with leaf liquorice extract dramatically reduced species richness to only one isolated strain, Pseudomonas asplenii, demonstrating the antibacterial effect already observed on bacteria isolated in clinical trials [24] and more recently against strains isolated from different artwork materials [18]. This effect was still evident in the combined liquorice-lavender treatment, where the 
number of isolated strains was reduced to three, all belonging to Proteobacteria. The treatment with lavender alone, although it did not reduce biodiversity greatly, did induce a species replacement with the appearance of strains belonging to Firmicutes and Actinobacteria.

\subsection{In Situ Treatments}

Following the well plate experiments, three areas of Room 93 covered by phototrophic biofilms were treated in situ by spraying with liquorice and benzalkonium. Data obtained comparing the effects of the two biocides are reported in Figures 6 and 7.

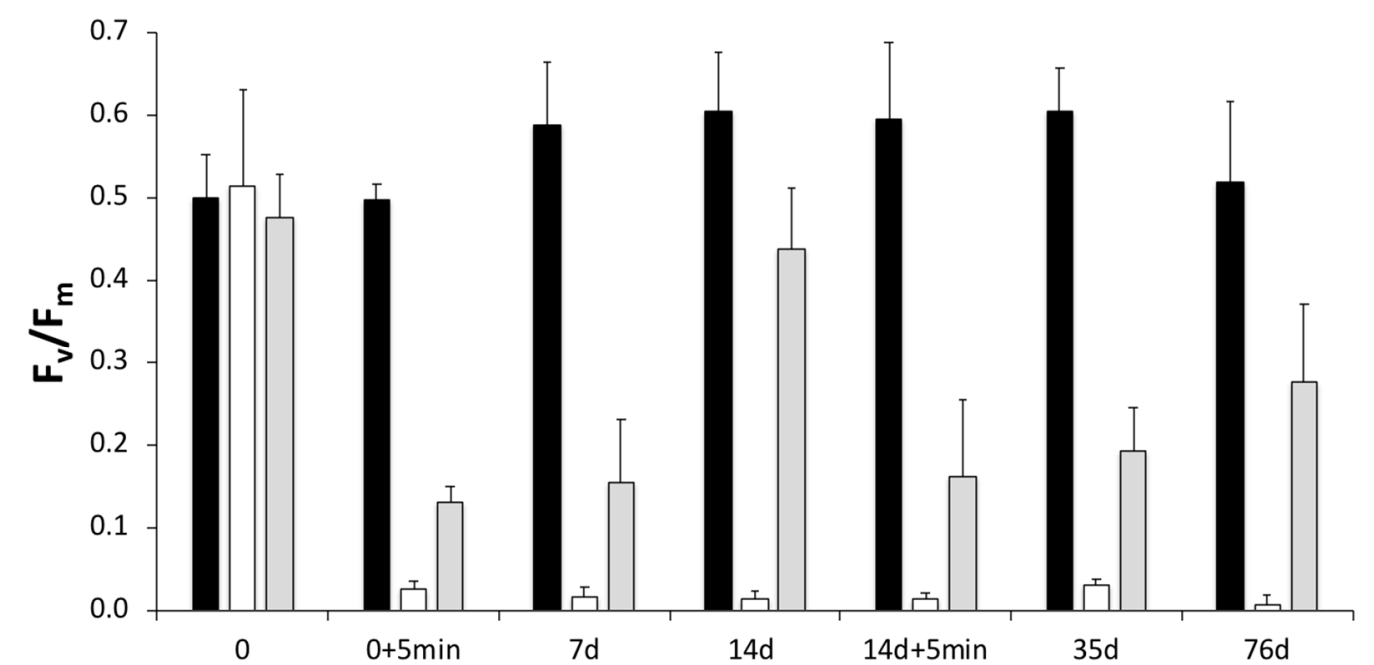

Figure 6. In situ treatment of biofilms growing in Room 93 of the Domus Aurea, Rome. Three treatments (CTRL (black), BENZ (white), LIQ (grey)); two applications, the first on day 0 and the second on day 14. PAM fluorometer measurements of yield were made immediately before both treatment applications ( 0 and 14 day), $5 \mathrm{~min}$ after ( $+5 \mathrm{~min}$ ), then on days 7 and 14 after the first application, and then on days 35 and $76(n=3)$.

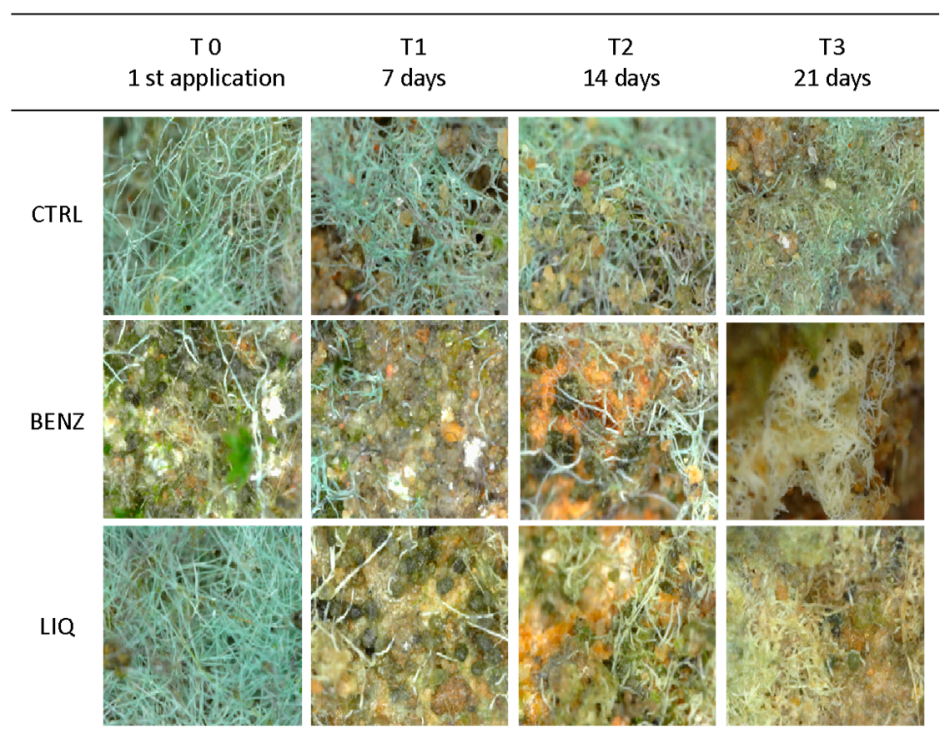

Figure 7. In situ Digital Microscope pictures of the treated surfaces at different time intervals acquired with Handheld Digital Microscope (USB) Dino-Lite Premier 1.3 MP (AnMo Electronics Corporation, Taiwan). The effect of LIQ and BENZ on the discolouration of the biofilms is evident.

The photosynthetic yields (Figure 6), measured $5 \mathrm{~min}$ after the application of benzalkonium, were significantly lower than the control and the liquorice treated biofilms $(p<0.05)$. However, 
yield recovery in the biofilms treated with the liquorice extract was almost complete by day 14, when compared to the control $(p<0.05)$, but after the second treatment yield remained 57\% lower than the control by day 76. This suggests a possible chronic effect of the treatments or that a higher concentration of the active ingredients is needed to have a lasting effect.

Images of the treated areas taken weekly until 21 days are shown in Figure 7.

The biofilms collected 14 days after the first application were transferred to the lab and observed using light and stereo microscopes (Figure 8). As already observed with PAM measurements, both in situ and lab images showed that BENZ had a stronger effect on the photosynthetic cells, particularly evident in the filaments of $S$. julianum that turned from green to white. The liquorice extract also had a visible biocidal effect, albeit at a lower level, where photosynthetic cells turned from green to light yellow, although this was possibly due to the staining by the liquorice extract itself on the carbonaceous sheath of $S$. julianum. While it was not possible to continuously follow the biofilms, it would be intriguing to know if the presence of some green filaments in the liquorice-treated area were a sign of recovery by some resilient cells that could support the PAM fluorimetry data.

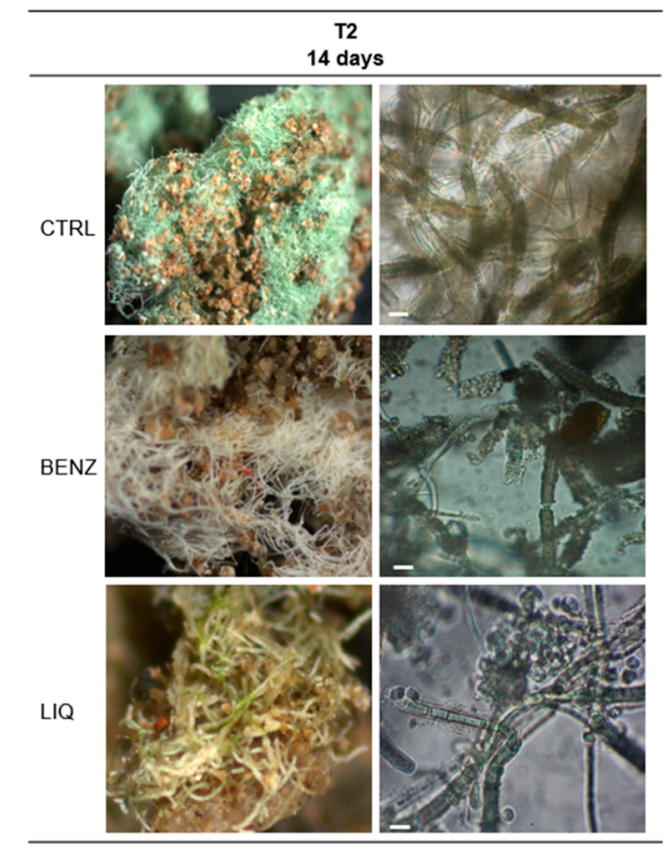

Figure 8. Images at stereo microscope (left column) and light microscope (right column) of in situ biofilms growing in Room 93 after 14 days and two applications of biocides. Bar $=10 \mu \mathrm{m}$.

To date, there are still no in situ studies containing detailed biofilm monitoring after treatments on a daily basis. This remains an intriguing challenge for future studies that should have a great impact on effective protocol development for biocide application for conservation purposes.

\section{Conclusions}

These studies performed in the prestigious sites of the Domus Aurea, Rome, took into consideration the majority of heterotrophic and phototrophic organisms forming subaerial biofilms, and the effects of biocide treatments on their function and composition. Liquorice alcoholic leaf extract (Glycyrrhiza glabra L.) was highly efficient in deterring phototrophic biofilm function and growth and when used in combination with lavender (Lavandula angustifolia Mill.) there was a further increase in the biocidal effect. This mixture (liquorice and lavender) also reduced the number of the cultivable heterotrophic bacteria strains in the biofilm, highlighting the widescale effect of these phyto-derivatives and showing the promise that these substances have when used, both alone and in combination. The application of the liquorice extract on the walls of Room 93 revealed how important it is to perform in situ trials to 
optimize the application of biocides for developing effective protocols, including to define the number of applications and the intervals between treatments.

Overall, the results obtained in this study showed that phyto-derivative products are promising as new non-invasive biocides to be employed for restoration and conservation actions of valuable sites. However, more on-site studies are needed with detailed follow-up monitoring to further understand their mechanisms.

Author Contributions: Conceptualization, G.M., F.T., A.R.S., L.B.; methodology, L.R., G.M., F.T., N.T.W.E., A.R.S., L.B.; validation L.R., G.M., F.T., N.T.W.E., L.B.; investigation, L.R., G.M., F.T., N.T.W.E., L.B.; data curation, L.R., G.M., F.T., N.T.W.E., L.B.; writing—original draft preparation, L.R., G.M., F.T., N.T.W.E., L.B.; writing一review and editing, L.R., G.M., F.T., N.T.W.E., A.R.S., L.B.; supervision, A.R.S., L.B. All authors have read and agreed to the published version of the manuscript.

Funding: This research received no external funding.

Acknowledgments: The authors grateful thank Alessandro D'Alessio e Maria Bartoli from the "Parco Archeologico del Colosseo" for the kind cooperation, the permission to work in the Domus Aurea, the precious opportunity given to us to put scientific research at the service of restoration and conservation, and the constant willingness to evaluate innovative solutions to ancient restoration problems. Isolated heterotrophic strains are included in the microbial collection ENEA-MIRRI-IT-MIcrobial Resource Research Infrastructure-Italian Joint Research Unit http://www.mirri-it.it/index.php/associated/enea/, member of the European MIRRI collection. The authors are thankful to A. Canini for giving us the lavender essential oil to test and the Trifolio-M GmbH for providing us with liquorice leaf extract.

Conflicts of Interest: The authors declare no conflict of interest.

\section{References}

1. Albertano, P.; Moscone, D.; Palleschi, G.; Hermosín, B.; Saiz-Jimenez, C.; Sanchez-Moral, S.; Hernández-Mariné, M.; Urzì, C.; Groth, I.; Schroeckh, V.; et al. Cyanobacteria attack rocks (CATS): Control and preventive strategies to avoid damage caused by cyanobacteriaand associated microorganisms in Roman hypogean monuments. In Molecular Biology and Cultural Heritage; Saiz-Jimenez, C., Ed.; Balkema: Amsterdam, The Netherlands, 2003; pp. 151-162.

2. Bruno, L.; Valle, V. Effect of white and monochromatic lights on cyanobacteria and biofilms from Roman Catacombs. Int. Biodeterior. Biodegrad. 2017, 123, 286-295. [CrossRef]

3. Mulec, J.; Kosi, G. Lampenflora algae and methods of growth control. J. Cave Karst Stud. 2009, 71, $109-115$.

4. Albertano, P. Cyanobacterial biofilms in monuments and caves. In Ecology of Cyanobacteria II: Their Diversity in Space and Time; Whitton, B.A., Ed.; Springer: Amsterdam, The Netherlands, 2012; pp. 317-343.

5. Urzì, C.; Bruno, L.; De Leo, F. Biodeterioration of paintings in caves, catacombs and other hypogean sites. In Art, Archaeology and Architecture; Mitchell, R., Clifford, J., Eds.; Archetype Publications Ltd.: London, UK, 2018; pp. 114-129.

6. Gaylarde, C.; Baptista-Neto, J.A.; Ogawa, A.; Kowalski, M.; Celikkol-Aydin, S.; Beech, I. Epilithic and endolithic microorganisms and deterioration on stone church facades subject to urban pollution in a sub-tropical climate. Biofouling 2017, 33, 113-127. [CrossRef] [PubMed]

7. Nugari, M.P.; Pietrini, A.M.; Caneva, G.; Imperi, F.; Visca, P. Biodeterioration of mural paintings in a rocky habitat: The Crypt of the Original Sin. Int. Biodeterior. Biodegrad. 2009, 63, 705-711. [CrossRef]

8. Koziróg, A.; Rajkowska, K.; Otlewska, A.; Piotrowska, M.; Kunicka-Styczy, A.; Brycki, B.; Nowicka-Krawczyk, P.; Ko’scielniak, M.; Gutarowska, B. Colonising organisms as a biodegradation factor affecting historical wood materials at the former concentration camp of Auschwitz II e Birkenau. Int. J. Mol. Sci. 2016, 17, 1364. [CrossRef] [PubMed]

9. Marano, F.; Di Rita, F.; Palombo, M.R.; Ellwood, N.T.W.; Bruno, L. A first report of biodeterioration caused by cyanobacterial biofilms of exposed fossil bones: A case study of the Middle Pleistocene site of La Polledrara di Cecanibbio (Rome, Italy). Int. Biodeterior. Biodegrad. 2016, 106, 67-74. [CrossRef]

10. Slimen, A.; Barboux, R.; Mihajlovski, A. High diversity of fungi associated with altered wood materials in the hunting lodge of "La Muette", Saint-Germain-en-Laye, France. Mycol. Prog. 2020, 19, 139-146. [CrossRef]

11. Urzì, C.; De Leo, F.; Krakova, L.; Pangallo, D.; Bruno, L. Effects of biocide treatments on the biofilm community in Domitilla's catacombs in Rome. Sci. Total Environ. 2016, 572, 252-262. [CrossRef] 
12. Barresi, G.; Cammarata, M.; Palla, F. Biocide. In Biotechnology and Conservation of Cultural Heritage; Palla, F., Barresi, G., Eds.; Springer International Publishing: Cham, Switzerland, 2017; pp. 49-65.

13. Bruno, L.; Rugnini, L.; Spizzichino, V.; Caneve, L.; Canini, A.; Ellwood, N.T.W. Biodeterioration of Roman hypogea: The case study of the Catacombs of SS. Marcellino and Pietro (Rome, Italy). Ann. Microbiol. 2019, 69, 1023-1032. [CrossRef]

14. Genova, C.; Fuentes, E.; Sanmartín, P.; Favero, G.; Prieto, B. Phytochemical Compounds as Cleaning Agents on Granite Colonized by Phototrophic Subaerial Biofilms. Coatings 2020, 10, 295. [CrossRef]

15. Ruffolo, S.A.; De Leo, F.; Ricca, M.; Arcudi, A.; Silvestri, C.; Bruno, L.; Urzì, C.; La Russa, M.F. Medium-term in situ experiment by using organic biocides and titanium dioxide for the mitigation of microbial colonization on stone surfaces. Int. Biodeterior. Biodegrad. 2017, 123, 17-26. [CrossRef]

16. Hsieh, P.; Pedersen, J.Z.; Bruno, L. Photoinhibition of cyanobacteria and its application in cultural heritage conservation. Photochem. Photobiol. 2014, 90, 533-543. [CrossRef] [PubMed]

17. Sanmartín, P.; Villa, F.; Polo, A.; Silva, B.; Prieto, B.; Cappitelli, F. Rapid evaluation of three biocide treatments against the cyanobacterium Nostoc sp. PCC 9104 by color changes. Ann. Microbiol. 2015, 65, 1153-1158. [CrossRef]

18. European Chemicals Agency. Impacts of REACH Restriction and Authorisation on Substitution in the EU; ECHA-20-R-09-EN978-92-9481-618-4; European Chemicals Agency: Helsinki, Finland, 2020. [CrossRef]

19. Genova, C.; Zoppis, E.; Grottoli, A.; Cencetti, C.; Matricardi, P.; Favero, G. An integrated approach to the recovery of travertine biodegradation by combining phyto-cleaning with genomic characterization. Microchem. J. 2020, 156. [CrossRef]

20. Abbas, A.; Zubair, M.; Rasool, N.; Rizwan, K. Antimicrobial Potential of Glycyrrhiza glabra. J. Drug Des. Med. Chem. 2015, 1, 17-20.

21. Gupta, V.K.; Fatima, A.; Faridi, U. Antimicrobial potential of Glycyrrhiza glabra roots. J. Ethnopharmacol. 2008, 116, 377-380. [CrossRef]

22. Fatima, A.; Gupta, V.K.; Luqman, S.S.; Negi, A.S.; Kumar, J.K.; Shanker, K.; Saikia, D.; Srivastava, S.; Darokar, M.P.; Suman, P.S. Antifungal activity of Glycyrrhiza glabra extracts and its active constituent glabridin. Phytother. Res. 2009, 23, 1190-1193. [CrossRef]

23. Fukui, H.; Katsumi, G.; Tabata, M. Two antimicrobial flavanones from the leaves of Glycyrrhiza glabra. Chem. Pharm. Bull. 2008, 36, 4174-4176. [CrossRef]

24. Irani, M.; Sarmadi, M.; Bernard, F.; Ebrahimi, G.H.; Ebrahimi, G.H.; Bazarnov, H.S. Leaves antimicrobial activity of Glycyrrhiza glabra L. Iran. J. Pharm. Res. 2010, 9, 425-428.

25. Bassyouni, R.H.; Kamel, Z.; Megahid, A.; Samir, E. Antimicrobial potential of licorice: Leaves versus roots. Afr. J. Microbiol. Res. 2012, 6, 7485-7493.

26. Scherf, A.; Treutwein, J.; Kleeberg, H.; Schmitt, A. Efficacy of leaf extract fractions of Glycyrrhiza glabra L. against downy mildew of cucumber (Pseudoperonospora cubensis). Eur. J. Plant Pathol. 2010, 134, 755-762. [CrossRef]

27. Sprocati, A.R.; Alisi, C.; Migliore, G.; Marconi, P.; Tasso, F. Sustainable restoration through biotechnological processes: A proof of concept. In Roles of Microorganisms in Heritage Degradation and Preservation; Springer: Cham, Switzerland, 2020. (in press)

28. Urzì, C.; De Leo, F. Sampling with adhesive tape strips: An easy and rapid method to monitor microbial colonization on monument surfaces. J. Microbiol. Methods 2001, 44, 1-11. [CrossRef]

29. Komárek, J. Cyanoprokaryota: 3rd part: Heterocytous genera. In Süswasserflora von Mitteleuropa 19/3; Büdel, B., Gärtner, G., Krienitz, L., Schagerl, M., Eds.; Springer Spektrum: Heidelberg/Berlin, Germany, 2013; p. 1130.

30. Komárek, J.; Anagnostidis, K. Cyanoprokaryota. 2nd part: Oscillatoriales. In Süsswasserflora von Mitteleuropa 19/2; Büdel, B., Krienitz, L., Gärtner, G., Schagerl, M., Eds.; Elsevier Spektrum: Heidelberg, Germany, 2005; p. 759.

31. Mühling, M.; Woolven-Allen, J.; Murrell, J.C.; Joint, I. Improved group-specific PCR primers for denaturing gradient gel electrophoresis analysis of the genetic diversity of complex microbial communities. ISME J. 2008, 2, 379-392. [CrossRef] [PubMed]

32. Dayan, F.E.; Zaccaro, M.L.M. Chlorophyll fluorescence as a marker for herbicide mechanisms of action. Pestic. Biochem. Phys. 2012, 102, 189-197. [CrossRef] 
33. Schreiber, U.; Neubauer, C.; Schliwa, U. PAM fluorometer based on medium-frequency pulsed X-flash measuring light: A highly sensitive new tool in basic and applied photosynthesis research. Photosynth. Res. 1993, 36, 65-72. [CrossRef] [PubMed]

34. Bruno, L.; Bellezza, S.; De Leo, F.; Urzì, C. A study for monitoring and conservation in the Roman Catacombs of St. Callistus and Domitilla, Rome (Italy). In The Conservation of Subterranean Cultural Heritage; Saiz-Jimenez, C., Ed.; CRC Press, Taylor \& Francis Group: London, UK, 2014; pp. 37-44.

35. Eckhardt, F.E.W. Mechanisms of the microbial degradation of minerals in sandstone monuments, medieval frescoes and plasters. In Proceedings of the 5th International Congress on Deterioration and Conservation of Stone, Lausanne, Switzerland, 25-27 September 1985; Felix, G., Ed.; Presses Polytechniques Romandes: Lausanne, Switzerland, 1985; Volume 2, pp. 643-665.

36. Alberano, P.; Urzì, C. Structural interactions among epilithic cyanobacteria and heterotrophic microorganisms in Roman hypogea. Microbiol. Ecol. 1999, 38, 244-252. [CrossRef]

37. Saarela, M.; Alakomi, H.L.; Suihko, M.L.; Maunuksela, L.; Raaska, L.; Mattila-Sandholm, T. Heterotrophic microorganisms in air and biofilm samples from Roman catacombs with a special emphasis on actinobacteria and fungi. Int. Biodeterior. Biodegrad. 2004, 1, 27-37. [CrossRef]

38. Krakova, L.; De Leo, F.; Bruno, L.; Pangallo, D.; Urzì, C. Complex bacterial diversity in the white biofilms of St. Callixtus Catacombs in Rome evidenced by different investigation strategies. Environ. Microbiol. 2015, 17, 1738-1752. [CrossRef]

39. Di Martino, S. Bacterial adherence: Much more than a bond. AIMS Microbiol. 2020, 4, 563-566. [CrossRef]

40. Limoli, D.H.; Jones, C.J.; Wozniak, D.J. Bacterial extracellular polysaccharides in biofilm formation and function. In Microbial Biofilms, 2nd ed.; Ghannoum, M., Parsek, M., Whiteley, M., Mukherjee, P.K., Eds.; American Society of Microbiology: Washington, DC, USA, 2015. [CrossRef]

41. Miller, A.Z.; Laiz, L.; Gonzalez, J.M.; Dionísio, A.; Macedo, M.F.; Saiz-Jimenez, C. Reproducing stone monument photosynthetic-based colonization under laboratory conditions. Sci. Total Environ. 2008, 278-285. [CrossRef]

42. Mihajlovski, A.; Gabarre, A.; Seyer, D.; Boust, F.; Di Martino, P. Bacterial diversity on rock surface of the ruined part of a French historic monument: The Chaalis abbey. Int. Biodeterior. Biodegrad. 2017, 120, 161-169. [CrossRef]

43. Blom, C.W.P.M. Adaptations to flooding stress: From plant community to molecule. Plant Biol. 1999, 1, 263-273. [CrossRef]

44. Murchie, E.H.; Lawson, T. Chlorophyll fluorescence analysis: A guide to good practice and understanding some new applications. J. Exp. Bot. 2013, 64, 3983-3998. [CrossRef] [PubMed]

45. Kusama, Y.; Inoue, S.; Jimbo, H.; Takaichi, S.; Sonoike, K.; Hihara, Y. Zeaxanthin and echinenone protect the repair of photosystem II from inhibition by singlet oxygen in Synechocystis sp. PCC 6803. Plant Cell Physiol. 2015, 56, 906-916. [CrossRef]

46. Proia, L.; Morin, S.; Peipoch, M.; Romaní, A.M.; Sabater, S. Resistance and recovery of river biofilms receiving short pulses of Triclosan and Diuron. Sci. Total Environ. 2011, 409, 3129-3137. [CrossRef]

47. Lüttge, U.; Büdel, B. Resurrection kinetics of photosynthesis in desiccation-tolerant terrestrial green algae (Chlorophyta) on tree bark. Plant Biol. 2010, 12, 437-444. [CrossRef]

48. Gray, D.W.; Lewis, L.A.; Cardon, Z.G. Photosynthetic recovery following desiccation of desert green algae (Chlorophyta) and their aquatic relatives. Plant Cell Environ. 2007, 30, 1240-1255. [CrossRef]

(C) 2020 by the authors. Licensee MDPI, Basel, Switzerland. This article is an open access article distributed under the terms and conditions of the Creative Commons Attribution (CC BY) license (http://creativecommons.org/licenses/by/4.0/). 